dr Jadwiga Szymaniak

Gdańska Wyższa

Szkoła Humanistyczna

Filia Koszalin
Eliminacja wykluczenia społecznego, red. M. Duda, K. Kutek-Sładek, Kraków 2017, s. 103-126 (Praca Socjalna w Teorii i Działaniu, 3).

DOI: http://dx.doi.org/10.15633/9788374385824.08

\title{
Wsparcie dziecka przewlekle chorego i jego rodziny
}

\author{
Support for a chronically ill child \\ and his family
}

\begin{abstract}
The support concept is trying to embrace common elements of upbringing and education. The relationship between the supporting person and supported person is explored by the anthropology. It emphasizes a strong "spiritual self" and the inner experiences of the individual. However, there is lack of sufficient documentation of the best contemporary practices in this field. The support term the most common occurs in social pedagogy. Today, it is supported by the social work at school and
\end{abstract}

pedagogical therapy. Teaching support becomes a teaching method - emphasizes comparative pedagogy. The pedagogy of creativity indicates that creative interests and intellectual curiosity of an ill child can be developed by a teaching content. The original ideas can always come to mind, even in disease.

Keywords: pedagogical support, pedagogical therapy, positive psychology, hope, gratitude

W pedagogice chrześcijańskiej znajdziemy wiele przykładów i wskazań, jak towarzyszyć dzieciom i młodym ludziom w chorobie i cierpieniu. Współcześnie są one coraz bardziej podbudowywane empirycznie, towarzyszą im teorie naukowe i naukowe obserwacje. Postęp w dziedzinie medycyny powoduje, że choroba nie musi być wyrokiem, a czas choroby zmarnowany. Wychowawcze "towarzyszenie" młodemu pacjentowi to „stwarzanie mu sprzyjających warunków rozwoju psychicznego i podjęcie wspólnej drogi prowadzącej do autonomii 
i optymalnego rozwoju"1. Towarzyszą rodzice, nauczyciele, wychowawcy, terapeuci, kapłani. Filozofowie chrześcijańscy, na przykład Jacques Maritain, na plan pierwszy wysuwali wewnętrzne siły tkwiące w wychowankach. Dorośli służą im w procesie umacniania. Porządek taki proponował już Ignacy Loyola (14911556), inspirator późniejszej pedagogiki ignacjańskiej. Towarzyszenie wymaga fizycznej obecności, wspólnego podążania, na które podopieczny wyraża zgodę. Zakłada to wnikliwe przyjrzenie się każdemu z podopiecznych z osobna, $\mathrm{z}$ empatią, $\mathrm{z}$ chęcią pomocy $\mathrm{w}$ tych przestrzeniach, gdzie dany człowiek jest najsłabszy. Ćwiczenia duchowne (Exercitia spirytualia) Loyoli kładły szczególny nacisk na rozwój duchowości, kategorii pojęciowej obecnej też we współczesnej myśli pedagogicznej. Zdumiewa ona u Loyoli, szlacheckiego syna, oficera hiszpańskiego, ciężko ranionego przy oblężeniu Pamplony przez Francuzów (rok 1521), który po okaleczeniu uniemożliwiającym karierę wojskową żmudnie uzupełniał wykształcenie, studiując filozofię i teologię (1528-1535) na Sorbonie, w wieku lat 40 uzyskał stopień magister atrium (dziś doktorat) ${ }^{2}$. Jego duchowy habitus to troska o duszę. Rozpoczął od legend o świętych i rycerzach, na łożu ciężkiej choroby, z ranną nogą. Czytał Jakuba de Voragine’a, autora Złotej legendy, chciał dorównać tym wielkim postaciom, gdyby życie oficera nie było już dla niego możliwe ze względu na kalectwo. Pielgrzymował też do Ziemi Świętej. Najważniejszym jego dokonaniem było założenie Towarzystwa Jezusowego, istniejącego do dziś, znanego z wysokich kwalifikacji intelektualnych swoich członków, służących szczególnie młodzieży akademickiej, potem też uczniom, w szkołach i konwiktach w całej Europie. Troska o morale przychodzących, wysokie wymagania, które mieli sobie stawiać wychowankowie, doprowadziły do tego, że zaczęto mówić o jezuickiej pedagogice szkolnej w ramach humanizmu w całej Europie ${ }^{3}$.

W postaci Ignacego Loyoli ważne było szczególnie to, że nie oddziaływał tylko jako teoretyk wychowania, ale jako osobowość, człowiek przezwyciężający swoje fizyczne słabości. Tu liczyła się siła woli (miał trudności z chodzeniem po ciężkiej ranie, ale skupiał przy sobie pierwszych współbraci, paryskich studentów i absolwentów Sorbony, był niezwykle inteligentny, toteż trwali oni przy nim przez wiele lat). Mimo kalectwa fascynował energią, oddziaływał na ludzi o podobnej strukturze psychologicznej, nawet w kręgu wysokich dostojników (papieżt, królów, kardynałów, książęta, uczonych i zwykłych ludzi). Mimo rozwiązania

1 E. Dybowska, Wychowawcze towarzyszenie młodym ludziom inspirowane pedagogika ignacjańską, [w:] Młodzież wobec ponowoczesności, red. nauk. M. Duda, Kraków 2009, s. 118.

2 K. Erlinghagen, Ignatius von Loyola, [w:] Klassiker der Pädagogik, Bd. 1, Hrsg. von H. Scheuerl, München 1991.

3 K. Erlinghagen, Ignatius von Loyola, dz. cyt., s. 46. 
zakonu jezuitów w roku 1773 po kilkudziesięciu latach zakon odżył (1814) i próbuje, mimo zmienionych warunków, nadal służyć. Jest znany także w Polsce.

\section{Wsparcie jako naczelne pojęcie wszystkich pedagogicznych poczynań}

Termin „wsparcie” funkcjonuje w wielu obszarach pedagogiki. Wydaje się, że istotny jest przede wszystkim $\mathrm{w}$ definicji wychowania. Jedna $\mathrm{z}$ nich, autorstwa Wolfganga Brezinki, brzmi: „Jako wychowanie określamy działania, przez które ludzie próbują wspierać osobowość innych ludzi pod jakimś względem"4. Najbardziej istotne dla naszych rozważań wydaje się stanowisko Henryka Rotha (1906-1983), psychologa i pedagoga niemieckiego, który podkreślał w procesie wychowania przezwyciężanie cielesnych i duchowych trudności ${ }^{5}$. Etymologicznie rzecz ujmując, pojęcie wsparcia ma w kulturze pozytywne konotacje, stara się objąć wspólne elementy wychowania i kształcenia. Z punktu widzenia antropologii centralnym problemem jest jednak stosunek między wspierającym i wspieranym. Wspomniany Roth starał się przezwyciężać dziedziczno-biologiczny pesymizm, a nawet teorie socjalizacji, stawiał w centrum jednostkę i jej decyzje, mocne "ja” duchowe, świat wewnętrzny. Konsekwentnie definiował wychowanie jako proces, który nawiązuje wyraźnie do indywidualnych możliwości dorastających, a nie tylko do celów ustanawianych z zewnątrz. Podkreśla się jednak, że w pedagogice współczesnej brak dostatecznej dokumentacji dobrych praktyk w tym zakresie, brak wyczerpujących opisów. Dlatego nie będę stroniła od konkretów.

Najczęściej pojęcie wsparcia pojawia się w pedagogice społecznej. Jan Henryk Pestalozzi, który nie znał jeszcze pojęcia pedagogiki społecznej, ale może być uznany za ojca pracy jej formami, podkreślał, że wzajemnie przenikają się warunki, które człowieka „czynią”, jak i to, że człowiek te warunki tworzy. Chodziło mu zwłaszcza o kontekst moralny, w którym wzrastamy; sformułował słynną maksymę, którą chciałabym przytoczyć, bo nie straciła na aktualności: „To, co świeci w rodzinnym pokoju, ma potem świecić w ojczyźnie...”․ Podkreślał więc uniwersalne znaczenie kultury w rodzinie, która ma moc promieniowania.

4 Handbuch Förderung, Hrsg. K. H. Arnold, O. Grasman, A. Rakhkochkine, Weinheim-Basel, 2008, s. 45 (o ile nie podano inaczej, tłumaczenia pochodzą od autorki artykułu).

5 U. Behrens, Förderung. Die Perspektive der Antropologie, [w:] Handbuch Förderung, dz. cyt., s. 47.

6 B. Müller, Förderung aus der Perspektive der Sozialpädagogik, [w:] Handbuch Förderung, dz. cyt., s. 86. 
Oczywiście chodzi mi, ze względu na temat, o kulturę związaną z opieką i pomocą. Dziś rodzinne formy opieki wspierać powinny szkolna praca socjalna i inne formy działań wyspecjalizowanych instytucji. Znawcy z zakresu pedagogiki społecznej, podobnie jak przedstawiciele antropologii pedagogicznej zgodnie sygnalizują zauważalny brak kompetencji dla przypadków trudnych. A przecież indywidualne wsparcie to obowiązek właśnie szkoły. Ma ona tu mandat służby - zarówno dzieciom, jak i ich rodzinom. I nie chodzi tylko o dowolny „serwis”, podkreśla Burchard Müller, chodzi o to, by wspieranych uczniów „zdobyć" do współpracy w dokonywanej interwencji. Stąd obowiązek obustronnej lojalności - zarówno wobec celów szkoły, jak i poszanowania podmiotowości dzieci i rodziców.

Jest to lojalność „balansująca” - pedagogowie szkolni, wychowawcy czy pracownicy socjalni występują jako rzecznicy i przekaziciele potrzeb podopiecznych, a nie tylko interesu społecznego. Zresztą często źle pojętego, co obserwujemy przy mechanicznym, często niemal okrutnym przekazywaniu dzieci, także chorych, wyrwanych z ich rodzinnych środowisk - do placówek zastępczych. A dzieci, często także i młodzież, czasem jeszcze nie wiedzą, co to znaczy być obrońcą w swojej sprawie. Pedagogika szkolna, a głównie z jej stanowiska kreślę swoje słowa, stara się obecnie jak najbardziej wykorzystać dokonania współczesnej nauki. Jako naczelny problem i zadanie wysuwa przede wszystkim indywidualizację pracy, w zależności od potrzeb dorastających, także chorego dziecka. Żadne dziecko nie może być zepchnięte na krawędź społeczeństwa czy stygmatyzowane. Heterogeniczność, a więc różnorodność, nie ma też być traktowana jako obciążenie, ale jako ubogacenie w sensie wzajemnego obdarzania się bodźcami czy przemyśleniami ${ }^{7}$. Chodziłoby na przykład o to, jak aktywnie wspierać uczniów potrzebujących pomocy w ramach klasy. Koncepcja integracji i - ostatnio - inkluzji wspiera przełożenie wartości podstawowych na codzienność szkolną, a więc na przykład uczy, jak mimo utrudnień budować możliwość udziału dziecka słabszego czy chorego w życiu klasy, jak nie ranićludzkiej godności, a więc jak tworzyć kulturę pomocy - podkreśla Olga Graumann z Uniwersytetu w Hildesheim. „Jest zadaniem pedagogiki szkolnej, dydaktyki ogólnej i dydaktyk przedmiotowych [...] legitymizować konieczność budowy kultury wsparcia i wypracowania konstruktywnych jej koncepcji”". Najbardziej wydajnie robi się to w Finlandii. Finlandia od lat przoduje w międzynarodowych badaniach osiągnięć szkolnych PISA. Jakie aspekty pracy pedagogicznej, szczególnie wsparcia, okazują się „nośne" jako orientacje? W porównaniu z innymi krajami w Finlandii jest mniej

7 O. Graumann, Förderung und Heterogenität. Die Perspektive der Schulpädagogik, [w:] Handbuch Förderung, dz. cyt., s. 19.

8 O. Graumann, Förderung und Heterogenität..., dz. cyt., s. 20. 
godzin nauczania, ale nawet słabi uczniowie fińscy są ponad przeciętną krajów OECD. Wydaje się, że tajemnica fińskiego sukcesu leży w przestrzeganiu cech nauczycielskiego profesjonalizmu. Selekcja do zawodu jest staranna, corocznie tylko jedna dziesiąta ubiegających się jest przyjmowana na nauczycielskie studia $^{9}$. W społeczeństwie panuje duże uznanie zawodu, przenosi się to na kolejne generacje, prestiż rośnie. W kształceniu nauczycieli kładzie się nacisk na wysoką zdolność do refleksji (niem. Reflexionskompetenz)i chęć dalszego rozwoju. Obok nauczycieli są w szkole pedagogiczni asystenci i rozbudowane służby socjalne oraz medyczne. Odciążają one uczących, szczególnie przez poradnictwo. Już w czasie studiów wielką rolę odgrywają szkoły ćwiczeń, gdzie studenci integrują teorię kształcenia i metody badań. Stało się oczywiste, że uczący dalej, już bez studium, będą badać swoje nauczanie, towarzyszyć mu refleksją, publikować... Z badań wynika, że połowa wszystkich uczniów w wieku 16 lat co najmniej jeden raz w toku nauki otrzymywała wsparcie w nauce. Nauczyciela obliguje dokładne diagnozowanie tych uczniów, którzy mają zaległości. Szkoła dopasowuje się do zasobów, potencjału uczących się, a nie odwrotnie. Między innymi trudne warunki geograficzne powodują, że przeważają małe wspólnoty szkolne, gdzie panuje prawie rodzinny klimat uczenia się (tylko 3 proc. wszystkich szkół liczy więcej niż 500 uczniów). Badania pedagogiki szkolnej powinny więc między innymi skupić się na tym, jakie pedagogiczne środki stosują nauczyciele i jakie są tego efekty. Jako przykład mogą służyć: pomoc w wykonywaniu zadań domowych, nadrabianie zaległości, kursy językowe, korepetycje i środki pozaszkolne, szczególnie terapia specjalistyczna, również pedagogiczna.

W zakres kompetencji nauczycieli wchodzi też znajomość form pomocy możliwych do uzyskania przez rodzinę w środowisku lokalnym - uważa się w literaturze pedagogicznej.

Dydaktyka mówi tu o optymalizowaniu szkolnych procesów uczenia się ${ }^{10}$. Wiąże się to z dobrymi rozwiązaniami organizacyjnymi, także dla dzieci chorych i niepełnosprawnych, na przykład nauczaniem indywidualnym, szkołami przyszpitalnymi. Popularny jest nadal model kompensacyjny, zmierzający do poprawy hamujących kognitywny lub motywacyjny rozwój cech osobowości podopiecznych oraz wymagający adaptacji zadań do możliwości dzieci. Należy więc ustalić:

- zakres treści i czas jej opanowania;

- poziom wymagań regulowany z empatią;

9 Te i dalsze dane dotyczące Finlandii czerpię z artykułu S. Trumpa, A. Weideman, The Finnish Lessom- und was wir von ihr lernen Können, „Pädagogik” 2 (2014), s. 38-43.

10 K. H. Arnold, P. Richert, Unterricht und Förderung: Die Perspektive der Didaktik, [w:] Handbuch Förderung, dz. cyt., s. 26. 
- liczbę powtórzeń;

- konieczność pomocy, względnie stopień samodzielności;

- zdolność kooperacji z innymi ${ }^{11}$.

Wsparcie oznacza bowiem dobre wpływanie na rozwój danego młodego człowieka. W wypadku dziecka chorego zakres treści stanowi problem niezmiernie istotny, może bowiem rozwijać jego twórcze zainteresowania, jego ciekawość intelektualną, której znaczenie dla ogólnego rozwoju jest nie do przecenienia. Także bowiem dziecko chore może być twórcze (zagadnieniu pracy nad osobowością twórczą poświęciła wiele konstruktywnych uwag Dorota Ciechanowska ${ }^{12}$. Oryginalne pomysły mogą się nasuwać zawsze, także w chorobie, i są warte notowania i wspierania. Nie chodzi o „nauczanie” twórczości, ale o usuwanie przeszkód, które ją ograniczają, o otwieranie możliwości jej zaistnienia. „Myślenie twórcze, realizujące się w twórczej postawie, może stać się walorem codziennej egzystencji” podkreśla autorka, a najważniejszy w twórczości jest umysł. Wymaga to jednak podmiotowego stylu interakcji nauczyciela, terapeuty, rodziców i podopiecznych. Charakteryzuje się on orientacją na rozwój jednocześnie uczniów oraz nauczycieli czy rodziców ${ }^{13}$, posługujących się twórczą interpretacją programów szkolnych (w wypadku nauczycieli) czy innych zaleceń. Cytowani autorzy Karel Heinz Arnold i Peggy Richert mówią o trzech wariantach wsparcia w przedmiotach szkolnych:

- wsparcie przez dodatkowy czas;

- wsparcie jako specyficznie spędzony czas;

- wsparcie jako towarzyszenie przez uczącego czy inne osoby, intensyfikacja pewnych działań czy zabiegów. Dochodzimy tu do pojęcia terapii pedagogicznej. Poświęcę jej kilka niezbędnych uwag. Chcę też przedtem dodać, że po z konieczności bardzo skrótowym zarysowaniu stanowiska antropologii pedagogicznej, pedagogiki społecznej, pedagogiki szkolnej i dydaktyki warto jeszcze wskazać na usiłowania pedagogiki porównawczej. Usiłuje się tu dokonać obserwacji międzynarodowych trendów, rośnie jej funkcja ewolucjonistyczna, szczególnie w kontekście globalizacji, podkreśla się aspekt praktyczny w zakresie poprawienia narodowych praktyk. Rysuje się wkład dużych badań międzynarodowych (wspomniana PISA), upowszechnia się projekty, szczególnie w dziedzinie poprawy komunikacji językowej i wspierania czytania, porównuje terminologię, bo buduje ona podstawę do wymiany

\footnotetext{
11 K. H. Arnold, P. Richert, Unterricht und Förderung..., dz. cyt., s. 28.

2 D. Ciechanowska, Twórczość w edukacji, Szczecin 2007.

3 D. Ciechanowska, Twórczość w edukacji, dz. cyt., s. 99.
} 
poglądów ${ }^{14}$. Trzeba przyznać, że w Unii Europejskiej nie obserwuje się jednoznacznych tendencji. Coraz częściej jednak mówi się o nauczaniu wspierającym jako metodzie nauczania ${ }^{15}$, postuluje się też powstanie nowej, inkluzyjnej pedagogiki i podkreśla znaczenie pracy szkolnych pracowników socjalnych.

\section{Terapia pedagogiczna}

Maria Pietniun przez terapię pedagogiczną rozumie system zintegrowanych i zaplanowanych w czasie zindywidualizowanych działań zapobiegawczych, stymulacyjno-usprawniających i korekcyjno-kompensacyjnych, realizowanych przez nauczycieli terapeutów poprzez różne formy pomocy specjalistycznej ${ }^{16}$. Jest to więc pewna forma interwencji wychowawczej, mającej na celu wywołanie sytuacji wychowawczych, najczęściej ich ciągu, które będą miały charakter terapeutyczny. Różnice między dziećmi wymagającymi terapii mogą dotyczyć wieku, poziomu umiejętności (szczególnie czytania i pisania), poziomu sprawności intelektualnych, modelu mikrouszkodzeń funkcji percepcyjno-motorycznych i reakcji na trudności ${ }^{17}$. Zadania dobierane są w zależności od diagnozy i powinny się mieścić w obszarze „strefy najbliższego rozwoju”. Sytuacji terapeutycznej powinny towarzyszyć pozytywna atmosfera i podkreślanie mocnych stron podopiecznych. Najczęściej mówi się o czterech aspektach oddziaływania terapeutycznego:

- aspekt psychoterapeutyczny występuje w interakcjach dziecko-terapeuta i łączy się z rozwijaniem motywacji oraz pokonywaniem trudności;

- aspekt psychodydaktyczny obejmuje przede wszystkim umiejętność czytania i pisania;

- aspekt psychokorekcyjny obejmuje przede wszystkim umiejętności dziecka, na miarę aktualnych i przyszłych potrzeb, stosowanie wybranych metod, ćwiczeń, pomocy;

- aspekt ogólnorozwojowy obejmuje pobudzanie i usprawnianie rozwoju psychoruchowego i emocjonalnego, poszerzanie wiedzy ogólnej i zainteresowań ${ }^{18}$.

14 A. Rakhkochkine, Förderung aus international vergleichender Perspektive, [w:] Handbuch Förderung, dz. cyt.

15 A. Rakhkochkine, Förderung aus international vergleichender Perspektive..., s. 58.

16 M. Pietniun, Próba formułowania teoretycznych podstaw terapii pedagogicznej, „Życie Szkoły" (1990), nr 2-3, s. 75.

17 M. Pietniun, Próba formułowania teoretycznych podstaw..., dz. cyt., s. 76.

18 M. Pietniun, Próba formułowania teoretycznych podstaw..., dz. cyt., s. 76. 
Obowiązują pewne zasady terapii, łączące się z zasadami ogólnopedagogicznymi. Na podkreślenie zasługują:

- zasada integracji, a więc łączenia w pracy terapeutycznej wiedzy na temat aktualnych potrzeb dziecka i jego możliwości z wiedzą o sposobach pomocy;

- zasada interkalacji, a więc ćwiczenia tej samej funkcji za pomocą różnych technik i środków w zmieniających się sytuacjach;

- zasada świadomego udziału dziecka w terapii ${ }^{19}$.

Obecnie pojęcie terapii pedagogicznej stosowane jest w odniesieniu nie tylko do osób chorych, ale także wobec jednostek o zaburzonym rozwoju lub w poszukiwaniu rozwiązań wobec sytuacji trudnych, również w stosunku do osób pozostających w obrębie patologii społecznej ${ }^{20}$. Chodzi o ulgę, o złagodzenie trudności w radzeniu sobie z własnymi problemami. Sądzę, że opis pracy, który zaczerpnęłam z literatury pedagogicznej, dobrze oddaje wymienione aspekty i zasady pracy terapeutycznej ${ }^{21}$.

Opisane dzieci, upośledzone umysłowo w stopniu lekkim, dotknięte różnymi schorzeniami (jak padaczka), przebywały w ośrodku wychowawczym, uczęszczały do klasy V i VI szkoły specjalnej. Praca z nimi miała charakter eksperymentu związanego z przygotowywanymi pracami magisterskimi opiekunek. Wytypowano 9 dzieci, zajęcia odbywały się 3 razy w tygodniu przez 6 miesięcy (od grudnia do maja). Uczniowie polubili spotkania. Kontynuowali ćwiczenia, wyjeżdżając do domu. Położono nacisk na poprawę motoryki i aspekt psychodydaktyczny w zakresie usprawnienia czytania i pisania. Uwzględniając zasadę interkalacji, starano się usprawniać motorykę za pomocą ruchu rozwijającego według Weroniki Sherborne, wykorzystywano terapię Newella C. Kepharta, ćwiczenia grafomotoryczne Marty Bogdanowicz oraz ćwiczenia słuchu fonematycznego w oparciu o metodę Teresy Gąsowskiej i Zofii Pietrzak-Stępkowskiej. W płaszczyźnie psychodydaktycznej wykorzystano między innymi metodę 18 struktur wyrazowych Ewy Kujawy.

Szeroka oferta proponowanych ćwiczeń świadczy o solidnym przygotowaniu terapeutek. Efekty półrocznej pracy były zaskakująco dobre. Dzieci nauczyły się czytać całościowo, poprawiły estetykę pisma, wzrosła ich aktywność na lekcji, postęp zaznaczył się też w zakresie motoryki małej (lepienie, malowanie, wycinanie, puzzle, wyszywanie).

19 M. Pietniun, Próba formułowania teoretycznych podstaw..., dz. cyt., s. 76.

20 J. Bolewska, Terapia pedagogiczna jako rodzaj oddziaływań wychowawczych $i d y$ daktycznych w pedagogice społecznej,[w:] Terapia pedagogiczna $w$ rehabilitacji osób niepetnosprawnych, pod red. K. Lucypera i A. Stankowskiego, Bielsko-Biała 2008, s. 81.

21 Autorką opisu jest Barbara Oszustowicz, Stymulowanie umiejętności czytania i pisania uczniów upośledzonych umysłowo w stopniu lekkim - analiza przypadku, [w:] Wspomaganie rozwoju, t. 3, red. B. Kaja, Bydgoszcz 2001. 
Należy docenić, że w myśli pedagogicznej poświęca się również uwagę korepetycjom. Wszak jest to forma wsparcia bazująca na efektywnym zagospodarowaniu czasu. Warto przyjrzeć się przemyśleniom dr Katarzyny Bielawnej, profesjonalnej korepetytorki języka angielskiego ${ }^{22}$. Autorka traktuje korepetycje jako wyzwanie, szczególnie gdy przedmiotem zabiegów jest uczeń niepełnosprawny lub chory. Dziecko takie może nie nadążać intelektualnie z powodu przerwy w nauce, może mieć trudności w porozumiewaniu się z rówieśnikami, którym nie zaszczepiono tolerancji ${ }^{23}$. Korepetytor dystansuje się od swoich wrażeń, nie może dać odczuć, że tempo pracy wolniejsze niż w klasie jest dla niego nużące. Praktyka nakazuje mu słuchać, co dziecko mówi o szkole, czasem bowiem potrzebna jest tam jego interwencja. Autorka pomija „rozbrykanych” nastolatków z „łatką ADHD”, niedbale piszących młodszych uczniów, niechętnych ćwiczeniom, z rzekomą dysgrafią...

Konieczne są wyczulenie na potrzeby podopiecznego, wsłuchanie w jego nastroje, świadomość poziomu intelektualnego i emocjonalnego; korepetycje to bowiem niełatwe doświadczenie dla obu stron. Dla ucznia jest to kontakt z obcym, nieznanym człowiekiem, szczególnie na początku.

Niektóre z tych uwag odnoszą się do nauczycieli ze szkół szpitalnych. Zadaniem ich jest przede wszystkim oddziaływanie terapeutyczne. „Nauczyciel stanowi tu dla ucznia symbol zdrowia i możliwości powrotu do życia sprzed choroby” - pisze Justyna Karolewska, nauczycielka w Zespole Szkół Szpitalnych w Szczecinie ${ }^{24}$. Nauka ma wspomagać proces leczenia „Zadaniem nauczyciela jest motywowanie i dołożenie wszelkich starań, aby dziecko wróciło ze szpitala silniejsze"25. Tok nauki ma przebiegać w harmonii z planem leczenia i być dostosowany do możliwości podopiecznego. Jak uczy obserwacja, dzieci hospitalizowane, przeżywające wizyty lekarzy i pielęgniarek, obciążone kroplówkami i lekami, chętnie jednak poszerzają wiedzę, aktywnie uczestniczą w zajęciach szkolnych i opiekuńczych. Czasem naukę przerywają ból lub złe samopoczucie. Nauczyciel ma więc różnorakie nowe obowiązki, musi na przykład poznać metodykę pracy w klasach łączonych - powinien być przygotowany na realizację różnych tematów na jednych zajęciach. Punktem wyjścia do działań pedagogicznych w szpitalu jest jednak zawsze program leczenia, zgodnie z którym planować należy oddziaływania terapeutyczne i dydaktyczno-wychowawcze ${ }^{26}$.

22 K. Bielawa, Wyzwanie edukacji. Korepetycje a potrzeby ucznia niepetnosprawnego, „Refleksje” (2015) nr 1, s. 32-34.

${ }^{23}$ K. Bielawa, Wyzwanie edukacji..., dz. cyt., s. 30.

24 J. Karolewska, Szkoła (nie) zwyczajna, „Refleksje” (2015) nr 1, s. 29.

25 J. Karolewska, Szkoła (nie) zwyczajna, dz. cyt., s. 29.

26 G. Krząkała, B. Wawszczyk, Specyfika integracji dzieci przewlekle chorych. Z doświadczeń nauczycieli ze szpitala dziecięcego w Zabrzu, [w:] O trudnej sztuce bycia razem, czyli 
Nauczyciel podejmuje wspólne działania z lekarzem, pielęgniarkami i psychologiem klinicznym, przyczynia się do aktywnego uczestnictwa dziecka we własnym procesie leczenia. Ma dać poczucie bezpieczeństwa, pewności, ładu, tworzyć atmosferę normalności. Towarzyszy mu jednak zawsze świadomość nadrzędności celów terapeutycznych nad dydaktycznymi. Dzieci mogą pisać bajki czy opowiadania, które są potem drukowane i rozpowszechniane. Czasem opowiadanie przekształca się w scenariusz. Znane są przykłady tworzenia dziecięcych pisemek z zagadkami, rebusami. Wspomniane autorki opisują "kolorowe dni” w szpitalu. Na przykład w Dniu czerwonym główne bohaterki dnia biedronki proponują gry i zabawy matematyczne, w Dniu zielonym górują zielone liście i utrwala się pisownię ze zmiękczeniami: zieleń, kwiecień, strumień, korzeń, słońce, uśmiech, bocian... Warto „zaaplikować” dzieciom piękny wiersz Urszuli Sobkowiak Krokusy:

\author{
Turystom \\ Wędrującym doliną \\ Śpiewają wiosnę \\ Graniom \\ Otulonym bielą \\ Malują nadzieję \\ Smrekom \\ Wytrwale zielonym \\ Szepczą ulotność... ${ }^{27}$
}

Gry i zabawy mają walory wspólnotowe. W trakcie ich trwania dzieci z przypadkowej grupy uczniów o różnych doświadczeniach i z różnym poziomem wiedzy, w różnym wieku przemieniają się we wspólnotę ${ }^{28}$, razem podejmującą działania na rzecz grupy. Tu spontanicznie kształtują się więzi społeczne, czasowo zerwane. Mogą też przebiegać ważne procesy socjalizacyjne - dzieci uczą się, że nie należy oceniać nikogo przez pryzmat choroby, choroba nie dyskredytuje. Jak piszą przywoływane autorki, najtrudniejszy jest typ pracy „przyłóżkowej”, zajęcia indywidualne. Nauczyciele bardzo je przeżywają, ponieważ są świadkami cierpienia. Również spotkania z rodzicami tych dzieci są niełatwe. Co im powiedzieć o sensie cierpienia? Myślę, że warto w tym kontekście przyjrzeć się założeniom psychologii pozytywnej.

\footnotetext{
różne oblicza integracji, pod red. A. Stankowskiego, M. Balukiewicz, Kraków 2006, s. 249.

27 U. Sobkowiak, Po horyzont, Bydgoszcz 2015, s. 31.

28 G. Krząkała, B. Wawszczyk, Specyfika integracji dzieci przewlekle chorych..., dz. cyt., s. 254 .
} 


\section{Propozycje psychologii pozyływnej}

Mówiąc o dziecku chorym, należy zwrócić się w kierunku propozycji tej psychologii. Przedstawię je najkrócej. Ułatwia to fakt, że właśnie ukazała się niezmiernie pożyteczna książka Michaeli Brohm i Wolfganga Andresa poświęcona jej założeniom i próbom ich przełożenia na codzienne życie szkolne ${ }^{29}$. Autorka, aktualnie dziekan Uniwersytetu w Trewirze, profesor w zakresie dydaktyki oraz współautor pedagog Wolfgang Endres poszukują tego, co człowieka wzmacnia i uzdrawia. Pionier psychologii pozytywnej, amerykański psycholog Martin Seligmann podkreślał, że psychologię pozytywną cechuje odwrót od nastawienia na deficyty, jak w „starej” psychologii klinicznej, i szukanie innego spojrzenia. Łączył je z „rozkwitaniem” (niem. Aufblühen). Brzmi to przyrodniczo, ale chodzi o rozkwitanie kognitywne, emocjonalne i psychospołeczne, a więc o całościowy wzrost człowieka ${ }^{30}$.

Psychologia pozytywna analizuje kilka czynników czy stanów, które budują nasze codzienne życie i są sprawdzalne empirycznie:

- przeżywanie pozytywnych emocji,

- prowokowanie motywacji i zaangażowania,

- wzmacnianie pozytywnych relacji,

- tworzenie sensu,

- bycie skutecznym.

W psychologii określa się je jako PERMA Modell (positive emotions, engagement, relations, meaning, accomplishment). Należy więc rozpocząć od tworzenia pozytywnego „klimatu” wokół dorastających, w szkole i w domu, także w wypadku choroby. Przyjrzyjmy się tym kolejnym czynnikom pod kątem kontaktów $\mathrm{z}$ dzieckiem chorym.

\section{Przeżywanie pozyływnych emocji}

Chodzi tu zarówno o emocje prymarne (jak radość czy zainteresowanie), jak i wynikające z wychowania (empatia, wdzięczność). Amerykańska psycholog Barbara Fredrikson sformułowała teorię rozumienia wartości i oceniania emocji (tzw. broaden-and-build theory). W teorii tej wychodzi się z założenia, że pozytywne emocje poszerzają repertuar myślenia i działania, budują osobowe „zasoby” (niem. Ressourcen) w czterech centralnych zakresach - intelektualnym, fizycznym, społecznym i psychicznym. Zwiększać się więc może kompetencja

${ }_{29}^{29}$ M. Brohm, W. Endres, Positive Psychologie in der Schule, Weinheim-Basel 2015.
30. Brohm, W. Endres, Positive Psychologie in der Schule, dz. cyt., s. 16. 
rozwiązywania problemów, następuje szybsze uczenie się nowych informacji, rozwija też koordynacja ruchowa, społecznie wspierana jest jakość przyjaźni i innych związków, rozwija się również umiejętność przeciwstawiania się przeciwnościom, tzw. Resilienz. Zwłaszcza ten ostatni aspekt, wspomniana Resilienz (ang. resilency, a więc zdolność do oporu), wydaje się szczególnie ważny w odniesieniu do dzieci chorych czy ich opiekunów. Osoby zdolne do takich reakcji, mimo na przykład utrapień związanych z chorobą, nie popadają w dalsze problemy. Wykształciły w sobie skuteczność i inne społeczne umiejętności ${ }^{31}$.

W świetle tej teorii pozytywne emocje, jeśli występują częściej, długotrwale nas zmieniają. Natomiast negatywne - zacieśniają, ograniczają repertuar myśli i działań, czynią nas „ciasnymi” w głowie i w sercu. Dawno potwierdzono empirycznie wpływ pozytywnych emocji na zdrowie, zwłaszcza zaobserwowano efekty dotyczące pracy serca i krążenia.

Nie bez znaczenia dla chorych jest na przykład fakt, że należy uczyć się „przestrukturyzowania” sytuacji, aby umieć znaleźć sens także w smutnym zdarzeniu ${ }^{32}$. Psychologia pozytywna mówi tu o wyrabianiu w sobie właśnie siły, wspomina o charakterze - pojęciu, któremu ostatnio przywraca się należne znaczenie i blask. Psychologia pozytywna wskazuje więc na mądrość i wiedzę, odwagę, człowieczeństwo i miłość, sprawiedliwość, umiarkowanie i transcendencję. A także na nadzieję i wdzięczność. Poświęcę kilka słów wdzięczności, bo jest to kategoria rzadko omawiana w naszej literaturze pedagogicznej. Ostatnio z punktu widzenia religii i właśnie pedagogiki szkolnej ujął ją Klaus Mertes SJ ${ }^{33}$. Wskazał on na jej znaczenie w duchowości wspomnianego już Ignacego Loyoli, twórcy pedagogiki chrześcijańskiej, doświadczonego kalectwem na skutek wojennych ran. Ignacy Loyola uzasadniał, że komunikacja we wspólnocie to wymiana wdzięczności, podziękowań - nie tylko, ale przede wszystkim. Dotyczy biorących, ale i dających, którzy mogą się uczyć od swoich podopiecznych i dziękować im za zaufanie.

Wdzięczność jest wymogiem sprawiedliwości. Tak zresztą widzieli ją już antyczni filozofowie, szczególnie Sokrates, jako uniwersalnie obowiązujące „niepisane prawo”. Ignacy Loyola wskazywał tė̇, ̇̇e „ćwiczenie wdzięczności jest [...] kluczowym ćwiczeniem duchowości nauczycielskiej”34. Drugi krąg zagadnień szczególnie rozpatrywanych przez psychologię pozytywną dotyczy motywacji i zaangażowania. Przypomnę studium empiryczne przeprowadzone niedawno

31 Pojęcie Resilienz dobrze objaśniają H. E. Tenorth, R.Tippelt, Beltz Lexikon Pedagogik, Weinheim-Basel 2012, s. 604.

32 M. Brohm, W. Endres, Positive Psychologie in der Schule, dz. cyt., s. 25.

33 Patrz rozdział Dankbarkeit w cytowanej książce M. Brohm i W. Endresa, s. 176-180.

34 M. Brohm, W. Endres, Positive Psychologie in der Schule, dz. cyt., s. 179. 
na uniwersytecie w Monachium, gdzie Kou Murayama, Reinhard Pekrun i inni w roku 2012 przebadali 3,5 tys. uczniów w zakresie matematyki. Okazało się, że motywacje i strategie uczenia się miały większy wpływ na osiągnięcia z tego przedmiotu niż inteligencja ${ }^{35}$.

Także dziecko chore może stawiać sobie cele ambitne i osiągalne. Nauczyciel może stać się modelem w niektórych zakresach, na przykład „zarażać” optymizmem. Uczenie się przy modelu to nadal jeszcze najsilniejsza empirycznie dowiedziona siła oddziaływania w pedagogicznych stosunkach. Dzieci na przykład chętniej czytają, gdy widzą chęć czytania u dorosłych. Jeśli chcemy wzmocnić specyficzne zachowanie, musimy je pokazać. Chodzi też o entuzjazm nauczyciela wobec nauczanego przedmiotu. Dla nauczyciela stworzono tu nawet profesjonalny rejestr zachowań, przydatny też w szkołach przyszpitalnych. Nauczyciel powinien więc dysponować:

- wyrazistą gestyką,

- zmienną intonacją głosu,

- stałym kontaktem wzrokowym,

- humorem,

- „żywymi” przykładami i przekonującymi komunikatami ${ }^{36}$.

„Najważniejsze jednak zachowanie, jakie możemy przekazać, to wiara w naszą własną skuteczność jako nauczyciela i skuteczność uczącego się, a więc wiara w jego dzielność" ${ }^{37}$. Wydaje się, że dziecka chorego dotyczy to w szczególności.

Czynnikiem stymulującym aktywność uczących się jest lekka niepewność emocjonalna, szczególnie wobec zadań do wykonania, które powinny być trochę egzotyczne, nowe, niecodzienne, aby pobudzały ciekawość.

Stymulujące są też różne dziedziny doświadczeń - raz kognitywne, innym razem emocjonalne, społeczne, audytywne czy manualne, bo ludzie muszą myśleć, czuć, odczuwać, działać, aby rozwijać się całościowo. Oczywiście wiele zależy tu od inwencji pedagogów pracujących z dziećmi. Może nawet więcej niż od zasobów środowiska. W każdym razie starajmy się „przybliżyć dziecku świat do łóżka”, wyrobić jego ciekawość - psychologia pozytywna traktuje ją jako jeden z najważniejszych fenomenów. Badaczem w skali światowej jest w tym zakresie angloamerykański psycholog Tod Kashdan. Ciekawość otwiera na nowe doświadczenia, radość, oczarowanie. Jej wysoki poziom na przykład u dzieci 3-letnich koreluje wyraźnie $\mathrm{z}$ inteligencją tych dzieci w wieku lat 11 podaje Michaela Brohm.

${ }_{35}$ M. Brohm, W. Endres, Positive Psychologie in der Schule, dz. cyt., s. 43.
M. Brohm, W. Endres, Positive Psychologie in der Schule, dz. cyt., s. 45.
${ }_{37}$ M. Brohm, W. Endres, Positive Psychologie in der Schule, dz. cyt., s. 46. 
Kolejne postulaty psychologii pozytywnej są może trudniejsze do realizacji, choć niezmiernie istotne. Wzmacnianie pozytywnych relacji dotyczy często tylko pozytywnych kontaktów chorego dziecka z rodziną, personelem medycznym, wolontariuszami czy nielicznymi rówieśnikami. Czasem dziecko ponownie „uczy się żyć”. Cenne uwagi na ten aspekt pracy z nim zawarte są w polskiej literaturze pedagogicznej. Profesor Anna Murawska z Uniwersytetu Szczecińskiego zwraca uwagę na to, że zgodnie z zasadą epigenetyczną żaden okres rozwojowy nie jest izolowany od pozostałych ${ }^{38}$. Erik Erikson dopuszczał kategorię „nowych narodzin”, odbudowę sił witalnych. Rozwój człowieka, zdaniem Eriksona, na żadnym etapie nie jest przesądzony. I nawet przebywając poza szkołą, odczuwając samotność, można dystansować się od własnego stanu, włączając się w miarę swoich możliwości w sprawy innych ${ }^{39}$. Trzeba dziecko w tym wspierać, także aby uznało własną osobę za wartość. I również w tym kontekście należy wrócić do wdzięczności. Relacji na niej opartych trzeba się uczyć. Może warto zachęcić chore dziecko do prowadzenia dziennika czy pamiętnika, w którym zapisze swoje wspomnienia i przeżycia $z$ okresu walki z chorobą i pokaże tych, którzy w tej walce pomagali? Stworzy ich portret czy „rysunek ze słów”?

Czwarty element modelu psychologii pozytywnej - tworzenie sensu - może odegrać ważną rolę w kontaktach z dzieckiem chorym. Nie chodzi tu tylko o jego wychowanie, ale szczególnie o próby tworzenia homo crescens, tak jak to ujmował Henryk Roth, o poszukiwanie wzrostu, możliwości rozwoju. O radość związaną z procesem uczenia się, o dociekliwość poznawczą na indywidualną miarę.

Wszak i nadzieja, w ujęciu psychologii poznawczej, ma swój poznawczy składnik, a więc system przekonań dotyczący też siebie, rozumienia siebie, swojego położenia, projektowania siebie. Wymaga to intelektualnego wysiłku ${ }^{40}$. Trzeba się tu odwołać szczególnie do przemyśleń Viktora Emanuela Frankla (1905-1997), psychologa, neurologa i filozofa, twórcy logoterapii, który przestrzegał przed tak zwaną "egzystencjalną frustracją" ${ }^{41}$. Michaela Brohm podaje kilka pytań, na które nauczyciel powinien sobie odpowiedzieć:

- Czy daje dziecku oparcie i ochronę dla jego „ja”?

- Czy daje mu bliskość emocjonalną i fizyczne „poruszenie”?

- Czy odnosi się z szacunkiem do dziecka i jego rodziny, przestrzegając poszanowania wartości i uznania?

38 A. Murawska, Edukacja w trosce o nadzieję człowieka, [w:] Ku integralności edukacji i humanistyki, red. Z. Kwieciński, M. Jaworska-Witkowska, Toruń 2008, s. 685.

39 A. Murawska, Edukacja w trosce o nadzieję człowieka, dz. cyt., s. 687.

40 A. Murawska, Edukacja w trosce o nadzieję człowieka, dz. cyt., s. 683.

41 M. Brohm, W. Endres, Positive Psychologie in der Schule, dz. cyt., s. 77. 
Autorzy dochodzą więc też do pojęcia dydaktyki optymistycznej, pojmowanej jako sztuka nauczania, przezwyciężająca ewentualny opór. Dydaktyka optymistyczna pojmuje bowiem nauczyciela jako artystę, ponieważ potrafi on stworzyć dobry klimat do nauki, stopniowo prowadzący do odnalezienia rzeczy ważnych. Brohm i Endres przytaczają w tym kontekście rozliczne świadectwa, także ludzi dorosłych, formułowane z perspektywy lat. Jeśli chcemy więc stanowić sens w pedagogicznym ujęciu, musimy stale na nowo pytać, jak uczynić naszych podopiecznych (w miarę możliwości także tych chorych) „ciekawymi”, „otwartymi”. Ich i ich opiekunów. Zainteresowanych nie tylko sobą.

Ostatni element rozpatrywany przez pozytywną psychologię to poczucie skuteczności (niem. Wirksamsein). Obejmuje ono zdolności i umiejętności, szczególnie rozwiązywania problemów, ale także chęć doprowadzenia sprawy do końca, a więc osiągnięcie celu. Psychologowie mówią w tym zakresie o aktywnym zdobywaniu koncepcji siebie.

Rola wiedzy w budowaniu tej koncepcji jest zasadnicza, wiedza z określonych dziedzin bezsprzecznie dodaje odwagi („Jestem dobra z matematyki, na pewno zdam egzamin...").

Poczucie skuteczności orientuje na przyszłość,wspiera inne czynniki wzmacniające. Nazywane jest „gorącą zmienną”, ustalono, że wpływają tu szczególnie doświadczenia rodzące się w najbliższym środowisku (rodzina i szkoła). Jeszcze w latach 70. Richard J. Shavelson, Judith J. Hubner podzielili naszą wiedzę o sobie na dziedziny:

- akademicką i szkolną (obejmuje przedmioty nauczane na kolejnych etapach),

- nieakademicką (składają się na nią sądy rówieśników, emocjonalna koncepcja siebie i osiągnięcia związane z ciałem, jak siła i wytrzymałość).

Wprowadzili też kategorię oceny zachowań w specyficznych sytuacjach ${ }^{42}$.

Obie dziedziny (akademicka i nieakademicka) mogą się różnić (np. „historia mnie fascynuje”, ale: „nie mam przyjaciół...”). Oczywiście zawsze dużą rolę odgrywa nadzieja. Kluczowe powiedzenie wspomnianego już psychologa Martina Seligmana brzmiało: „Nadzieja, optymizm i zorientowanie na przyszłość to rodzina sił" 43 .

Albert Bandura wskazał na cztery źródła poczucia własnej skuteczności:

- przeżyte doświadczenia („niepowodzenia generują niepowodzenia”),

- zaobserwowane przykłady,

- osąd innych,

- sygnały cielesne (stres, poty...).

${ }^{42}$ M. Brohm, W. Endres, Positive Psychologie in der Schule, dz. cyt., s. 92.

43 M. Brohm, W. Endres, Positive Psychologie in der Schule, dz. cyt., s. 94. 
Dlatego tak ważne jest, aby naszym uczącym się dawać nadzieję co do ich skuteczności („Ty to umiesz, a jeśli nie, to możesz się nauczyć...”).

Ostatnio też inni psychologowie (Fritz Heider, Bernard Weiner 1994) zwrócili uwagę na wpływ wysiłku, nastroju, zmęczenia czy choroby. Podkreślają wagę zmiany przez wysiłek i podzielanie określonych przekonań („Wszyscy mogą nauczyć się matematyki”). Zwłaszcza psycholog M. Kay Alderman (2008) akcentuje rolę wysiłku, starań i pilności, dawania z siebie tego, co najlepsze ${ }^{44}$. U uczniów osiągających słabe wyniki zaobserwował on małe zaufanie do siebie, brak prób bardziej intensywnej pracy.

Co ważne i co warto jeszcze raz podkreślić, oczekiwania nauczyciela wobec uczniów pozostają w ścisłym związku z jego własnym poczuciem skuteczności („Potrafię nauczyć”).

Wydaje się, że przytoczenie, w największym skrócie, założeń psychologii pozytywnej, może stać się pożyteczne w niełatwych kontaktach z chorymi dziećmi i ich opiekunami.

\section{Dziecko chore a rodzina. Pojęcie choroby przewlekłej. Kategoria nadziei i transcendencji}

„Zespoły leczące [...] w praktyce medycznej oczekują aktywnej współpracy rodziny na kolejnych etapach leczenia" ${ }^{45}$. Istnieją oczekiwania, że pomoc rodzinna pobudzi siły odpornościowe organizmu chorego. Wbrew powszechnym przekonaniom choroba dziecka może jednoczyć rodzinę, chronić przed rozpadem. Dawne rodziny wielopokoleniowe odgrywały tu dużą rolę, ułatwiały opiekę, kształtowały, jak się wydaje, jednostki bardziej odporne na stres. System rodzinny może więc być źródłem oparcia i poczucia bezpieczeństwa dziecka lub źródłem jego zaburzeń oraz ryzyka pogłębiania się choroby. Zawsze konieczne jest podtrzymywanie słabnącej samooceny i pozytywnego obrazu siebie u pacjenta ${ }^{46}$. Nieraz zresztą rodzina chorego dziecka bardziej niż ono samo potrzebuje wsparcia. „Dzieci chore wyczuwają lęk i zmartwienie rodziców, ukrywają przed nimi swoją wiedzę o zagrożeniu [...], nie ujawniają własnego lęku, w ten sposób chroniąc rodziców przed większą rozpaczą" ${ }^{37}$. Jest to dowód

44 M. Brohm, W. Endres, Positive Psychologie in der Schule, dz. cyt., s. 97.
B. Gulla, Rodzinny wymiar choroby dziecka, [w:] Rodzina wobec zagrożé, pod red.

M. Dudy, Kraków 2008, s. 118.

46 B. Gulla, Rodzinny wymiar choroby dziecka, dz. cyt., s. 124,

47 B. Gulla, Rodzinny wymiar choroby dziecka, dz. cyt., s. 125. 
miłości dziecka. Dziecko, które już wie, że jest poważnie chore i być może umrze, chciałoby o tym porozmawiać, podzielić się lękiem, ale tego nie robi. Zostaje ze swoim strachem osamotnione - pisze Bożena Gulla. Postępowanie rodziców zależy od ich własnych zasobów, dojrzałości emocjonalnej, odporności psychicznej, także od wsparcia społecznego.

Nadmieńmy, że można zaobserwować też niekiedy postawę nadmiernego chronienia chorego dziecka, bez żadnych wymagań wychowawczych. „Jeżeli ma to miejsce w wypadku choroby przewlekłej, ale możliwej do wyleczenia, skutki takiego postępowania spowodują poważne trudności wychowawcze w przyszłości", uważa Bożena Gulla ${ }^{48}$. Zawsze natomiast trzeba budzić nadzieję, dotyczy to także rodzeństwa.

Należy podkreślić, że szczególne zagrożenie kryzysem rodzinnym z powodu choroby dziecka może nastąpić, gdy choroba współistnieje z biedą, bezrobociem, bezdomnością. Wśród wniosków dotyczących terapii rodziny i dziecka coraz częściej mówi się o wspomnianych już zasobach duchowych jednostek, o wspólnotach, także rodzinnych, jako przestrzeni rozwoju. Wspomniano o nadziei.

Pojęciu temu poświęca się uwagę zwłaszcza w ramach filozofii i katolickiej nauki społecznej. Nadzieja definiowana jest zarówno w kategoriach postawy ludzkiej, a więc jako pojęcie określające pozytywne nastawienie intelektualne, emocjonalne i psychiczne, jako i jako cnota teologiczna. Łącząc nadzieję z postawą, podkreśla się napięcie woli, dążenie do dóbr, które są trudne do zdobycia, w tym wypadku zdrowie ${ }^{49}$. Realizację pragnień, pozytywne nastawienie wobec tego, co ma nastąpić, akcentuje się silnie w w filozofii współczesnej, katolicka nauka społeczna zaznacza natomiast, że nie może być rozłamu między odległym celem, sformułowanym w myśl zasad wiary, a życiem codziennym, nadzieja chrześcijańska ma więc charakter społeczny, postuluje zaangażowanie, wspólnotowość, tolerancję $e^{50}$. Tolerancji wobec chorych często brak.

Przytoczę przykład Arka, licealisty ze Szczecina. Arek na skutek licznych infekcji i długotrwałego leczenia antybiotykami utracił odporność. Ma kochających i na szczęście zamożnych rodziców. Towarzyszyli mu w chorobie, kiedy był już w liceum. Arek jednak słabł. Dołączyło się przewlekłe zapalenie pęcherza. Chłopiec co kilkanaście minut zmuszony był do korzystania z toalety. Budziło to wielkie rozbawienie kolegów i koleżanek. Arek z trudem znosił tę sytuację. Na wniosek dyrekcji liceum przyznano mu w klasie maturalnej

48 B. Gulla, Rodzinny wymiar choroby dziecka.

49 Słownik - przewodnik filozoficzny. Osoby-problemy-terminy, red. nauk. A Maryniarczyk i in., Lublin 2012, s. 465.

50 Słownik katolickiej nauki społecznej, red. nauk. W. Piwowarski, Warszawa 1993, s. 111-112. 
nauczanie indywidualne. Pracował więc głównie sam. Z pomocą matki udało się znaleźć skuteczną terapię medyczną. Rodzina nie traciła nadziei. Arek wytrwale poddawał się leczeniu. Przezwyciężył chorobę i bardzo dobrze zdał egzamin dojrzałości. Pójdzie na studia. Widuję go. Aktywnie biega, jest pogodny. Nie stracił wiary w siebie.

Na ten aspekt samorozwoju zwraca uwagę prof. Władysława Pilecka z Uniwersytetu Jagiellońskiego ${ }^{51}$. Podczas gdy młodsze dzieci w chorobie i cierpieniu bronią się raczej poprzez reakcje wegetatywne, a ich dyskomfort może być złagodzony przez obecność matki, którą najczęściej trzymają za rękę, dorastający mogą nawet okazywać większą niż dotąd aktywność poznawczą, poszukiwać informacji, stosować samokontrolę; uczą się też korzystać ze wsparcia społecznego i duchowego. Jak podaje Pilecka, może jednak też wystąpić zamykanie się w sobie (self isolation), dystansowanie się, zaprzeczanie chorobie.

Na uwagę zasługuje zaobserwowana $\mathrm{w}$ badaniach transcendencja, a więc przekraczanie ograniczeń własnej psychofizyczności. Niemal 50 proc. dzieci potrafi zachować wewnętrzną i zewnętrzną równowagę w chorobie, niektóre przeżywają osobowy rozwój. Dla nich podstawową motywacją do działania jest pragnienie uchwycenia sensu - „dzieci te podejmują trudny proces autokreacji, czyli samowychowania ku wartościom" ${ }^{52}$, na przykład próby rozumienia sensu cierpienia, odkrywania swoich talentów. Teoretyczne podstawy opracował w tym zakresie wspominany w naszych rozważaniach Frankl. Według niego cierpienie jest atrybutem życia każdego człowieka, człowiek zajmuje wobec niego określoną postawę. Cierpienie może uwrażliwiać na innych, a nawet wzmacniać. A poszukiwanie sensu to pierwsza ludzka motywacja. Potwierdzają to badania empiryczne. Przytoczę wyniki jednego z nich.

Aleksandra Tobota, psycholog związana z Kliniką Chirurgii Onkologicznej Instytutu Matki i Dziecka w Warszawie mówi o „duchowości” wielu chorych ${ }^{53}$. Rozumie duchowość jako osobiste poszukiwanie znaczenia i celu określonych zjawisk. Nie musi ona być związana z religią. W chorobie długoterminowej sprzyja zdrowiu. Przypomnijmy, że w roku 2002 opisano związek długości życia osób zakażonych HIV z czterema czynnikami: poczuciem spokoju, wiarą, praktykami religijnymi, współczującym postrzeganiem innych, nieoceniającym.

Okazało się, że osoby spokojne, wierzące, uczestniczące w praktykach religijnych i nieoceniające innych- żyją znacznie dłużej - podaje Aleksandra Tobota.

51 W. Pilecka, Zmaganie się dziecka z przewlekłą chorobą somatyczną - od radzenia sobie do transcendencji, [w:] Dziecko przewlekle chore - problemy medyczne, psychologiczne i pedagogiczne, red. nauk. B. Antoszewska, Torun 2011.

${ }_{52}$ W. Pilecka, Zmaganie się dziecka z przewlekłą chorobą..., dz. cyt., s. 17.

53 A. Tobota, Duchowość w życiu młodziėzy z chorobą nowotworową, [w:] Dziecko przewlekle chore..., dz. cyt., s. 10. 
Inne czynniki sprzyjające zdrowieniu to wysoki poziom nadziei, wsparcie społeczne, zachowania prozdrowotne, nastawienie altruistyczne.

W kontekście tym często przytacza się słowa Jana Pawła II, wypowiedziane już po tragicznym zamachu na Jego życie: „cierpienie otwiera drzwi nadziei” ${ }^{4}$. Chodzi bowiem o interpretację choroby w kategoriach zadania czy wyzwania. Wtedy będzie szansą rozwoju dojrzałej, bogatej wewnętrznie osobowości ${ }^{55}$. Nie bez znaczenia jest rodzaj choroby. Jest wiele klasyfikacji chorób. O chorobie krótkotrwałej mówimy, gdy trwa do trzech miesięcy, może mieć ostry przebieg, ale rokuje wyzdrowienie. Choroba przewlekła (powyżej trzech miesięcy) może utrzymywać się latami, a nawet nasilać się w miarę upływu czasu, pomimo leczenia i rehabilitacji ${ }^{56}$.

Według Amerykańskiej Komisji do Spraw Chorób Przewlekłych „za chorobę przewlekłą uznaje się takie zaburzenia i odchylenia od normy, które posiadają jedną lub więcej z następujących cech:

- są trwałe, pozostawiają za sobą inwalidztwo,

- spowodowane są przez nieodwracalne zmiany patologiczne,

- wymagać będą długotrwałego leczenia, nadzoru, obserwacji czy opieki,

- wymagają specjalistycznego postępowania rehabilitacyjnego" ${ }^{57}$.

W Polsce wszystkie osoby dotknięte chorobą przewlekłą mogą ubiegać się o otrzymanie orzeczenia o niepełnosprawności lub orzeczenia o stopniu niepełnosprawności, umożliwiających korzystanie z ulg w komunikacji, podatkowych, pocztowo-telewizyjnych, do świadczeń pomocy społecznej i otrzymywania dodatków pielęgnacyjnych oraz usług opiekuńczych. Reguluje to prawo ${ }^{58}$. Wydano odpowiednie akty wykonawcze dotyczące:

- chorób psychicznych (02-P),

- epilepsji (06-E),

${ }^{54}$ Jan Paweł II, Pamięć i tożsamość, Kraków 2005, s. 172.

55 Warto przypomnieć, że A. Tobota przebadała 2 grupy młodzieży, razem 90 osób, w wieku 18-20 lat, zarówno pacjentów z rozpoznaną chorobą nowotworową, jak i młodzież ostatnich klas szkół średnich i studentów. Badania miały pozwolić ocenić poziom religijności, wrażliwość etyczną, harmonię wewnętrzną i poziom samodoskonalenia. Wynikło z nich, że osoby chore wykazały się istotnie statystycznie wyższym poziomem duchowości jako religijności, chorzy też okazali się w swoich deklaracjach bardziej wrażliwi etycznie, bardziej „zharmonizowani”. Nie górowali jednak w zakresie samodoskonalenia, pojmowanego jako twórczość i świadome dążenie do doskonalenia siebie. Generalnie potwierdził się wniosek, że „świadome przeżywanie choroby może nadać życiu wartość”.

${ }_{56}$ M. Gołubiew-Konieczna, Dzieci i młodzież przewlekle chora w systemie polskiej oświaty-próba oceny, [w:] Dziecko przewlekle chore..., dz. cyt., s. 41.

57 M. Gołubiew-Konieczna, Dzieci i młodzież przewlekle chora..., dz. cyt., s. 41.

58 Ustawa z dnia 27 sierpnia 1997 r. o rehabilitacji zawodowej i społecznej oraz zatrudnianiu osób niepełnosprawnych, Dz.U. 1997 nr 123 poz. 776 z późn. zm. 
- układu oddechowego i krążenia (07-S),

- układu pokarmowego (08-T),

- układu moczowo-płciowego (09-M),

- neurologiczne (10-N), inne.

Osoby przewlekle chore są stawiane na równi z osobami niepełnosprawnymi. Dzieci przewlekle chore mogą otrzymać z poradni psychologiczno-pedagogicznych opinię wspierająca, w której specjaliści wskazują na konieczność otoczenia ich opieką, troską i proszą, by dostosować pracę do możliwości wysiłkowych ${ }^{59}$.

Chcę też zwrócić uwagę na ostatnio upowszechniające się w Polsce pojęcie dziecka o specjalnych potrzebach edukacyjnych (narodziło się ono w Wielkiej Brytanii w latach 70., od 1994 roku jest upowszechniane przez UNESCO). Pojęcie wskazuje na cztery zakresy potrzeb:

- komunikacja i kontakty międzyludzkie,

- procesy myślowe i przyswajanie informacji,

- zachowania, emocje i rozwój społeczny,

- rozwój zmysłów i fizyczny ${ }^{60}$.

W klasyfikacji tej ujęte są też dzieci przewlekle chore. Jak podkreśla Grzegorz Szumski, dzieci o specjalnych potrzebach edukacyjnych nie są w stanie sprostać wymaganiom szkolnego uczenia się bez specjalnej pomocy pedagogicznej ${ }^{61}$. Godny podkreślenia jest fakt, że o dziecku z takimi potrzebami mówi się nie tylko w kategoriach prawnych, ale i etycznych. Znawcy tematyki kształcenia nauczycieli zwracają uwagę na konieczność zinternalizowania pojęć aksjologicznych w toku przygotowania do zawodu. Może to rzutować na przyszły kształt i zaangażowanie w pracę, decydować o wyborze specjalnych metod, wymagających większego wysiłku ze strony nauczających ${ }^{62}$. Konstytucja Rzeczypospolitej Polskiej z dnia 2. kwietnia 1997 stanowi, że „władze publiczne są obowiązane do zapewnienia szczególnej opieki zdrowotnej dzieciom”63.

59 M. Gołubiew-Konieczna, Dzieci i młodzież przewlekle chora..., dz. cyt., s. 42.

${ }^{60}$ K. Moczia, J. Godawa, Kwestie interpretacji pojęcia „specjalne potrzeby edukacyj$n e ",[\mathrm{w}:]$ Nauczyciel i rodzina $w$ świetle specjalnych potrzeb edukacyjnych dziecka, pod red. A. Stankowskiego, Katowice 2008, s. 14.

${ }^{61}$ K. Moczia, J. Godawa, Kwestie interpretacji pojęcia..., dz. cyt., s. 15.

${ }^{62} \mathrm{~K}$. Gabryś, O współodpowiedzialności rodziców i pedagogów za rozwój dziecka O specjalnych potrzebach edukacyjnych, [w:] Nauczyciel i rodzina w świetle specjalnych potrzeb edukacyjnych, dz. cyt., s. 24.

${ }^{63}$ Prawa dziecka jako pacjenta dogłębnie omówiła B. Szczupał, Prawa dziecka przewlekle chorego jako pacjenta - konwencje i uwarunkowania realizacji, [w:] Dziecko przewlekle chore..., dz. cyt. 


\section{Dziecko w hospicjum. Rola wolontariatu. Potrzeba wychowania do nieszczęścia}

Hospicja starają się ulżyć ludziom w cierpieniu spowodowanym przez nieuleczalną chorobę. Ruch hospicyjny w Polsce ma ponad 40 lat i rozwija się głownie z inicjatywy Kościoła - większość hospicjów należy do instytucji kościelnych (Caritas, zakony) lub organizacji świeckich, ale blisko związanych z Kościołem. Warto przywołać zasługi niektórych kapłanów w rozwoju ruchu hospicyjnego. Myślę tu o ks. Eugeniuszu Dutkiewiczu SAC (1947-2002), który położył podwaliny pod polski model hospicjum domowego, w roku 1984 założył hospicjum pallotyńskie w Gdańsku. Dzieci, jak sądzę, przebywają najczęściej w hospicjach domowych. Instytucje te opierają swoją działalność na zasadzie wolontariatu. Dotyczy to lekarzy, pielęgniarek i specjalistów, jak i innych opiekunów ${ }^{64}$. Opieka jest kompleksowa i dotyczy sfery zarówno fizycznej, jak i duchowej. Prowadzenie hospicjum domowego jest trudniejsze niż prowadzenie stałej placówki hospicyjnej lub zakładu opieki paliatywnej. Wolontariusze spędzają w takim domu po kilka godzin. Sprawowana być tam może też Eucharystia.

Jak podkreśla ks. Marek Kujawski SAC, od lat związany z posługą hospicyjną (kiedyś w Szczecinie, dziś dyrektor Hospicjum Królowej Apostołów w Radomiu), wolontariusze instruują bliskich, załatwiają potrzebny sprzęt. Opieką otacza się też członków rodziny.

Niestety, jak donosi prasa, hospicja nie zostały objęte pakietem onkologicznym $^{65}$. Istotne jest przygotowanie wolontariuszy do pracy, szczególnie do opieki nad dziećmi. Zajmuje się tym między innymi Fundacja Lubię Pomagać. Chodzi o pokazanie, na czym polega holistyczna opieka nad chorym, o aspekt prawny, o potrzeby psychiczne i duchowe, zarówno osoby chorej, jak i jej rodziny.

$\mathrm{Na}$ uwagę zasługują sympozja naukowe związane z tym tematem. Niedaleko terenów, na których mieszkam, w Sanktuarium Miłosierdzia Bożego w Myśliborzu odbyło się niedawno sympozjum na temat wolontariatu ${ }^{66}$. Istotnym aspektem spotkania była obecność młodzieży z myśliborskiego liceum, która pełni dzieło wolontariackie. Nie tylko pochylono się nad dziełem bł. ks. Michała Sopoćki, który przyczynił się do rozkrzewiania miłosierdzia, ale i ukazano konkretne wymiary rozumienia wolontariatu. Warto zwrócić uwagę na głosy profesorów Uniwersytetu Szczecińskiego. Na przykład prof. Alberto Lozano Platonoff ukazał nowe drogi, jakie otwierają się przed rozumieniem wolontariatu,

64 Hospicjum to téż zycie, „Nasz Dziennik” 7.01.2015.

65 A. Ambroziak, Hospicja poza pakietem, „Nasz Dziennik” 24-25.01.2015.

66 Ks. R. Gołębiowski, Wolontariat we współczesnym świecie, „Niedziela” (2015) nr 9. 
wskazując przy tym na ważność formacji przyszłych wolontariuszy, począwszy od dziecka poprzez szkołę aż do ukształtowania we współpracy z rodzinami trwałych postaw wolontariackich.

Dzieci z hospicjów, które nie mają odpowiednich warunków w domach rodzinnych, a których stan zdrowia się poprawił, trafiają najczęściej niestety do domów dziecka, a nie do rodzin, które naprawdę mogłyby im pomóc po odpowiednim przeszkoleniu. Pobyt w domu dziecka nie jest dla nich dobrą alternatywą. Przykładem takiego dziecka jest Patryk, podopieczny łódzkiej fundacji Gajusz. Dziecko, przebywając w hospicjum stacjonarnym, zrobiło ogromne postępy w rozwoju. Sąd zdecydował jednak, że chłopiec może trafić do pieczy zastępczej i umieścił go w domu dziecka. Chłopiec mieszkał na sali z kilkanaściorgiem dzieci, przechodził kolejne infekcje. Nie udało się go jeszcze umieścić w odpowiednio przeszkolonej rodzinie zastępczej. W ocenie rzecznika praw dziecka Marka Michalaka postanowienie, które nakazuje umieszczenie chłopca w instytucjonalnej pieczy zastępczej, jest wydane wbrew przepisom ustawy o wspieraniu rodziny.

Sprawdzoną alternatywą są bowiem specjalistyczne rodziny zastępcze. Takich jest jednak bardzo mało. Z danych ministerstwa pracy wynika, że w roku 2014 było ich 251, umieszczono w nich 568 dzieci. Rodziny te potrzebują wsparcia, także psychologicznego, za mało jednak robi się w tej dziedzinie ${ }^{67}$.

$\mathrm{Na}$ koniec chciałabym wspomnieć o ogromnym wyzwaniu, jakie dla edukacji stanowi przygotowanie do sytuacji w życiu trudnych. Wspomniana już wcześniej profesor Anna Murawska z Uniwersytetu Szczecińskiego stara się zgłębić - w sensie pedagogicznym - tak trudne pojęcie, jakim jest rozpacz ${ }^{68}$. Odwołując się do literatury z zakresu filozofii i psychologii, ale także pedagogiki, wykazuje, że na rozpacz nie powinno być wewnętrznej zgody, nie powinno być zgody na rezygnację z nadziei. „Doświadczenie rozpaczy trzeba wykorzystać do dokonania radykalnych zmian w sobie i w świecie” - pisze Murawska. Ale o jakich zmianach można mówić w sytuacjach osób terminalnie chorych, skoro cierpienie jest bezgraniczne? „Trzeba zaakceptować, że cierpienie i śmierć są częścią życia. A refleksję nad cierpieniem i śmiercią należałoby podjąć wcześnie. I to stanowi wspomniane trudne wyzwanie dla pedagogów” ${ }^{69}$. „Wychowanie do nieszczęścia” może, a nawet powinno stanowić część wychowania. Istnieją ku temu przesłanki teoretyczne w postaci przemyśleń psychologicznych i filozoficznych.

67 I. Borańska-Chmielewska, Za chore na dom, „Nasz Dziennik” 15.07.2015.

68 A. Murawska, Pokusa rozpaczy? Nadzieja wobec cierpienia i śmierci, [w:] Z pomoca człowiekowi. Wsparcie i opieka w sytuacjach nieuleczalnej choroby, red. B. Kromolicka, Toruń 2012, s. 52n.

69 A. Murawska, Pokusa rozpaczy? Nadzieja..., dz. cyt., s. 53. 
Trudność stanowi, być może, mentalność współczesnych społeczeństw, tak bardzo nastawionych na sukces, zdrowie, urodę. Chodzi więc także o szeroko pojętą edukację społeczną.

\section{Bibliografia}

Ambroziak A., Hospicja poza pakietem, „Nasz Dziennik” 24-25.01.2015.

Ambroziak A., Wolontariusz nie patrzy na zegarek, „Nasz Dziennik” 5.06.2015.

Arnold K. H., Richert P., Unterricht und Förderung. Die Perspektive der Didaktik, [w:] Handbuch Förderung, Hrsg. K. H. Arnold, O. Graumann, A. Rakhkocfhkine, Weinheim-Basel 2008.

Behrens U., Förderung. Die Perspektive der Anthropologie, [w:] Handbuch Förderung, Hrsg. K. H. Arnold, O. Graumann, A. Rakhkochkine, Weinheim-Basel 2008.

Beltz Lexikon Pädagogik, Hrsg. H. E. Tenorth, R. Tippelt, Weinheim-Basel 2012.

Bielawna K., Wyzwania edukacji. Korepetycje a potrzeby ucznia niepetnosprawnego, „Refleksje” (2015) nr 1, s. 34-36.

Bolewska I., Terapia pedagogiczna jako rodzaj oddzziaływań wychowawczych i dydaktycznych w pedagogice specjalnej, [w:] Terapia pedagogiczna w rehabilitacji osób niepetnosprawnych, pod red. K. Lucypera i A. Stankowskiego, Bielsko-Biała 2008.

Borańska-Chmielewska I., Za chore na dom, „Nasz Dziennik” 15.07.2015.

Brohm M., W. Endres, Positive Psychologie in der Schule, Weinheim-Basel 2015.

D. Ciechanowska, Twórczość w edukacji, Szczecin 2007.

Dybowska E., Wychowawcze towarzyszenie młodym ludziominspirowane pedagogika ignacjańską, [w:] Młodzież wobec ponowoczesności, red. nauk. M. Duda, Kraków 2009.

Erlinghagen K., Ignatius von Loyola, [w:] Klassiker der Pädagogik, I bd., Hrsg. von H. Scheuerl, München 1991.

Gabryś K., O współodpowiedzialności rodziców I pedagogów zarozwój dziecka o specjalnych potrzebach edukacyjnych, [w:] Nauczyciel I rodzina w świetle specjalnych potrzeb edukacyjnych dziecka, pod red. A. Stankowskiego, Katowice 2008.

Gołębiowski R., Wolontariat we wspótczesnym świecie, „Niedziela” (2015) nr 9.

Gołubiew-Konieczna M., Dzieci i młodzież przewlekle chora w systemie polskiej oświaty próba oceny, [w:] Dziecko przewlekle chore, red. nauk. B. Antoszewska, Toruń 2011.

Graumann O., Förderung und Heterogenität. Die Perspektive der Schulpädagogik, [w:] Handbuch Förderung, Hrsg. K. H. Arnold, O. Graumann, A. Rakhkochkine, WeinheimundBasel 2008.

Gulla B., Rodzinny wymiar choroby dziecka, [w:] Rodzina wobec zagrożeń, pod red. M. Dudy, Kraków 2008.

Hospicjum to téż życie „Nasz Dziennik” 7.01.2015.

Jan Paweł II, Pamięć i tożsamość, Kraków 2005. 
Müller B., Förderung aus der Perspektive der Sozialpädagogik, [w:] Handbuch Förderung, Hrsg. K. H. Arnold, O. Graumann, A. Rakhkochkine, Weinheim-Basel 2008.

Mertes K., Dankbarkeit - Uber die Freude des Gebens und Nehmens, [w:] M. Brohm, W. Endres, Positive Psychologie in der Schule, Weinheim-Basel 2015.

Moczia K., Godawa J., Kwestie interpretacji pojęcia „specjalne potrzeby edukacyjne”, [w:] Nauczyciel i rodzina w świetle specjalnych potrzeb edukacyjnych dziecka, pod red. A. Stankowskiego, Katowice 2008.

Murawska A., Edukacja w trosce o nadzieję człowieka, [w:] Ku integralności edukacji i humanistyki, red. Z. Kwieciński i M. Jaworska-Witkowska, Torun 2008.

Murawska A., Pokusa rozpaczy? Nadzieja wobec cierpienia i śmierci, [w:] Z pomoca człowiekowi. Wsparcie i opieka w sytuacjach nieuleczalnej choroby, red. B. Kromolicka, Torun 2012.

Oszustowicz B., Stymulowanie umiejętności czytania i pisania uczniów upośledzonych umysłowo w stopniu lekkim- analiza przypadku, [w:] Wspomaganie rozwoju, red. B. Kaja, Bydgoszcz 2001.

Pietniun M., Próba formułowania teoretycznych podstaw terapii pedagogicznej, „Życie Szkoły” (1990) $\mathrm{nr} 2-3$.

Pilecka W., Zmaganie się dziecka z przewlekła choroba somatyczna - od radzenia sobie do transcendencji, [w:] Dziecko przewlekle chore - problemy medyczne, psychologiczne i pedagogiczne, red. nauk. B. Antoszewska, Toruń 2011.

Rakhkochkine A., Förderung aus international vergleichende r Perspektive, [w:] Handbuch Förderung, Hrsg. K. H. Arnold, O. Graumann, A. Rakhkochkine, Weinheim-Basel 2008. Stownik - przewodnik filozoficzny. Osoby - problemy - terminy, red. A. Maryniarczyk i in., Lublin 2012.

Słownik katolickiej nauki społecznej, red. nauk. W. Piwowarski, Warszawa 1993.

Tobota A., Duchowość w życiu młodzieży z choroba nowotworowa, [w:] Dziecko przewlekle chore, red. nauk. B. Antoszewska, Toruń 2011.

Trumpa S., Weidermann A., The Finnis Lessom - und was wir von ihr lernen können, „Pädagogik" (2014) 2. 